\title{
Working capital management and profitability: evidence from Indonesian manufacturing companies
}

\author{
Irfan Aryawan ${ }^{1}$ and Astiwi Indriani ${ }^{1}$ \\ ${ }^{1}$ Department of Management, Faculty of Economics and Business, Universitas Diponegoro, Indonesia
}

\begin{abstract}
The aims of this study is to analyze the relationship between working capital management and profitability (return on assets) as a dependent variable and cash conversion cycle (CCC), inventory conversion period (ICP), average collection period (ACP) and average payment period (APP) as independent variables with leverage, liquidity, and size as the controlling variables. The sample of this study are manufacturing companies in the Indonesian Stock Exchange 2013-2017. The analysis using OLS showed that the ACP has a negative and significant effect on ROA and the APP has a positive and significant effect on ROA, meanwhile CCC and ICP has a negative and insignificant effect on ROA.
\end{abstract}

Keywords

return on assets (ROA); cash conversion cycle (CCC); inventory conversion period (ICP); average collection period (ACP); average payment period (APP)

\section{INTRODUCTION}

Manufacturing companies in Indonesia has become one of the most significant contributors for the country's economic growth. The growth of the medium and large manufacture industry in 2018 increased by $4.07 \%$ than that in 2017 . It is due to the increased production of leather, leather goods, and footwear industry (18.78\%), drinks $(23.44 \%)$, clothes $(13.17 \%)$, rubber, rubber goods, and plastic $(10.85 \%)$, and machinery and equipment $10.85 \%$. (Badan Pusat Statistik, 2018). They are also resistant to the financial crisis from 2007 to 2009. Manufacturing companies were an increase in profitability every year, and more manufacturing companies in Indonesian Stock Exchange than other sectors.

Similar with other companies, the main purpose of manucaturing company is to gain profitability because with the profitability of the company can perform its operational activities normally. For manufacturing companies, to get profitability, they need a large amount of working capital and also the efficiency of working capital management. This can be seen from the shorter working capital period, the company's profitability is also higher. However, the shorter working capital period will make companies have to rotate cash quickly, sell products quickly, and with the delay of debt payments with shorter periods will increase the company's obligations in the future. Therefore, the purpose of this research is to analyze the effect of cash conversion cycle (CCC), inventory conversion period (ICP), average collection period (ACP) and average payment period (APP) on Profitability with Leverage, Size, and Liquidity as Control variables.

This research is conducted on Indonesian manufacturing companies because there are differences between companies abroad and in Indonesia such as capital provisions invested and company size, this research tries to focus on three different manufacturing sectors. They are basic chemical industrial manufacturing, various industrial manufacturing companies, and consumer goods manufacturing companies.

Profitability is the company's ability to generate profit or return on sales, assets, and investments in a certain period. Profitability can be measured with ROA, ROE, and GOP methods. But in this study profitability measured with return on assets $(R O A) . R O A$ is the profitability ratio measured based on the company's net profit divided by total assets. This ratio was chosen because many researchers used the ratio in their studies such as Sharma and Kumar (2011), Mansoori and Muhammad (2012), Mogaka and Jagongo (2013), Samiloglu and Akgun (2016), Yakubu, Alhassan, and Fuseini (2017), Jakpar (2017), Kasozi (2017), and Shah, Gujar, and Sohu (2018). Besides, the reason using 
ROA is net profit data and total assets of manufacturing companies in Indonesia are presented by many companies with the annual financial reports so they are more easily accessed and obtained.

ROA is used to measure company ability to generate profits in a certain period and plan for future periods. ROA can produce the right decision in measuring profitability. If the net profit is higher than the assets, it will cause high net income, vice versa. the resulting ratio can be an alternative assessment in company performance when the company must take action to improve company performance.

The company's effort to getting profit is by maximizing the company's performance through operational activities in a manner, often corporate operational activities require a large number of costs to do this operational activity and make long-term investments, then working capital to be a source from company operational financing that can be used. in addition to generating large profitability, managers must manage working capital efficiently to support the company's operational activities, according to Mansoori and Muhammad (2012) said that the main purpose of working capital is to make sure that the company has cash flow enough to produce the good operational so that it can press inability to pay with a short period. Managers must try to avoid unnecessary investments in working capital. If it is not done, the amount of investment in working capital can reduce liquidity, so that working capital is inadequate and causes problems in daily operations.

Working capital management is the ability to effectively and efficiently control current assets and current Liabilities by returning assets and minimizing debt repayments of Mogaka and Jagongo (2013). One way to evaluate how well a company managing working capital with the CCC it's introduced by Richards and Laughlin (1980). This refers to the period between buying raw materials, converting products, selling products, and collecting receivables. Companies that have a shorter CCC, will have less investment in working capital as minimum funding Mansoori and Muhammad (2012).

CCC is a cash cycle period that starts from cash payment to meet production needs, such as processing raw materials into a product, billing for product sales, and payment of debt for the purchase of raw materials. When the CCC period is shorter, profitability will increase. This happens because the faster in getting cash payment more efficient, and effective to do company operations. This was confirmed by Jakpar (2017), Yakubu, Alhassan, and Fuseini (2017), Samiloglu and Akgun (2016), and Mogaka and Jagongo (2013). Pecking Order Theory is a funding decision in a company chooses to use internal funding than finance from external Myers and Majluf (1984). CCC is used as a company's internal funding to meet the company's needs in making profits. On the other side, a low CCC will produce low profitability, this difference from the theory that states that a low CCC will increase high profitability Sharma and Kumar (2011).

ICP according to Alipour (2011) is the period needed to change raw materials into products and then sell them. The shorter period from raw material to product, the higher the profitability obtained. That is because the more efficient the production process, the more product sold will get more profits. This statement is supported by research by Shah, Gujar, and Sohu (2018), Samiloglu and Akgun (2016), Yakubu, Alhassan, and Fuseini (2017), and Ponsian, Chrispina, and Tago (2014), and contrary with the statements of Mogaka and Jagongo (2013), Sharma and Kumar (2011), Jakpar et., al. (2017), and Kasozi (2017) they said that the average age of inventory of companies that have a long inventory period, will not shortages of supplies because it can increase their profits.

ACP is a period to change a company's debt to cash after the sale was calculated and dividing receivables with the average credit sales per day Ponsian, Chrispina, and Tago (2014). The faster collectible sales receivables so the faster cash will be obtained so that profitability is higher. This was supported by Yakubu, Alhassan, and Fuseini (2017), Kasozi (2017), Jakpar. et., al. (2017), Shah, Gujar, and Sohu (2018), Ponsian, Chrispina, and Tago (2014), and Mogaka and Jagongo (2013). And contrary to the statements of Bagh, Nazir, Khan, Khan, and Razzaq (2016) and Sharma and Kumar (2011) who examined 263 companies in India from 2000 to 2008 . The study explains that Indian manufacturing companies getting a long period to pay and produce high profitability so that Indian Company Managers increase profitability by 
increasing the loan period given to their customers.

ACP is a period for purchasing materials and paying workers with cash Ponsian, Chrispina, and Tago (2014). The longer the company pays the debt, the more capital is maintained for the company's operational activities to produce a profit. This is supported by the statements of Shah, Gujar, and Sohu (2018), Ponsian, Chrispina, and Tago (2014), Mogaka and Jagongo (2013), and Yakubu, Alhassan, and Fuseini (2017) and are in conflict with Sharma and Kumar (2011), Samiloglu and Akgun (2016), Bagh, Nazir, Khan, and Razzaq (2016), and Kasozi (2017) that some manufacturing companies pay creditors to improve the company's financial performance.

This study also uses control variables that can maintain the consistency of the effect of independent variables on the dependent. One of the control variables used in this research is leverage. Leverage used a company's external funds to pay for the company's internal resources. This is affects profitability. The lower leverage will increase profitability following the research of Vural, Sokmen, and Cetenak (2012). Other studies that use leverage as a control variable are Sharma and Kumar (2011), Mogaka and Jagongo (2013), and Samiloglu and Akgun (2016).

Liquidity has a relationship with profitability. Liquidity affects the profitability produced by the company. Liquidity is used as a control variable to maintain the consistency of the dependent variable without uninterrupted by variables that are not contained in this study. According to Alipour (2011) in his research explain that companies that have more liquidity will have a lot of profitability. Other studies that use liquidity as a control variable are Mogaka and Jagongo (2013) and Sharma and Kumar (2011).

Size is the basis of assets owned by the company. size has a relationship with profitability because assets of the company will affect profitability. Size is used as a control variable to maintain the consistency of the dependent variable in the research. Mogaka and Jagongo (2013) said that Size in their research has a relationship with profitability, because when ROA when it increases so Size will also increase. Other studies that use Size as a control variable are Sharma and Kumar (2011) Samiloglu and Akgun (2016), and Kasozi (2017).

\section{HYPOTHESES DEVELOPMENT}

\section{The effect of CCC on profitability (ROA)}

CCC is the length of time between the company's actual cash to pay productive resources, receive cash from product sales, collect receivables, and the length of time to pay workers and materials Ponsian, Chrispina, and Tago (2014). in the pecking order theory that companies use internal funding than financial sources from external sources. Sources of funds of cash are used first for the company's operating needs than having to use debt that can minimize profitability.

An increase in profitability can occur if the CCC period can be reduced by reducing the availability conversion period by selling product faster, reducing the receivables collection period with accelerating the collection of sales receivables and extending the debt suspension period by delaying the company's payment to creditors. This makes a negative relationship between the CCC with profitability. As one of the company's goals to reduce the CCC to improve company performance because the longer the CCC, the more company needs that must be provided financially, causing an increase in costs and lowering the value of the company as in the research of Alipour (2011). Several studies that have produced a negative relationship between $\mathrm{CCC}$ and profitability are Jakpar (2017), Yakubu, Alhassan, and Fuseini (2017), Samiloglu and Akgun (2016), and Mogaka and Jagongo (2013). Based on the explanation, it can be concluded that:

$$
\begin{aligned}
& \text { H1: CCC has a negative effect on } \\
& \text { profitability (ROA). }
\end{aligned}
$$

\section{The effect of ICP on profitability (ROA)}

The purpose of the ICP is to see the level of efficiency in managing processes from raw materials to products in the hope that the shorter the processing time, the higher level of efficiency that has impacted the increase in profitability. This happens because a high level of efficiency causes production costs decrease so that more and more products are produced and sold so faster to get cash. This is by research by Mansoori and Muhammad (2012) which explains that 
managers can increase profitability with shortening the time of the ICP. Research studies that have the same results as Mansoori and Muhammad (2012) namely, Shah, Gujar, and Sohu (2018), Samiloglu and Akgun (2016), Yakubu, Alhassan, and Fuseini (2017), and Ponsian, Chrispina, and Tago (2014) which shows that the ICP has a negative relationship with profitability. Based on the explanation, it can be concluded that:

H2: ICP has a negative effect on profitability (ROA).

\section{The effect of the ACP on profitability (ROA)}

The ACP is a measurement to determine the relationship between sales receivables and long-term uncollectible cash flows because the company does not obtain cash used to purchase raw materials, purchase and purchase production costs. If this happens it can decrease in profitability. As in the study of Ponsian, Chrispina, and Tago (2014) shows that increasing days to get payment from sales can increase company profitability, this resulting in a negative relationship. These results indicate that a decrease of 1 day can increase the level of profit. Other studies approved by Shah, Gujar, and Sohu (2018) agree that companies with low profitability can use insurance funds to reduce the CCC. The ACP has a negative relationship with profitability. Several studies support this result such as Mogaka and Jagongo (2013), and Yakubu, Alhassan, and Fuseini (2017). Based on the explanation, it can be concluded that:

H3: ACP has a negative effect on profitability (ROA).

\section{The effect of APP on profitability (ROA)}

The APP is defined as the time of payment for the purchase of raw materials and workers' payments. However, payments for company raw materials often go through debt. This happens as a way for companies to make payments less expensive and cash can be used for other purposes. This is same with the results of the research of Ponsian, Chrispina, and Tago (2014) which explains that companies hold payments to suppliers and use available cash for the company's working capital needs. Yakubu, Alhassan, and Fuseini (2017) also have the same opinion that the longer a company pay its debt, the more capital is retained for the company's operations so that it can generate profits. some research explains that the APP has a positive relationship with profitability such as Gujar, and Sohu (2018), and Mogaka and Jagongo (2013). Based on the explanation, it can be concluded that:

H4: APP has a positive effect on profitability (ROA).

In this research, profitability is measured using ROA to measure net income against assets. Working capital management can affect profitability with use one measure of working capital, that is the CCC which shows a negative relationship to profitability (ROA) because of the opposite relationship between the period of the CCC to increase and decrease profitability. In the measurement of the CCC, there is an ICP which shows a negative relationship to profitability (ROA) due to the opposite with the ICP to increase and decrease profitability. In addition to the ICP, there is also an ACP which has a negative relationship to profitability, this is because there is an inverse relationship between the ACP period to increase and decrease profitability. In addition to the ACP, there is an APP which has a positive relationship with profitability, which means that it has a direct relationship between the APP period to increase and decrease profitability.

In addition to the relationship of working capital management with profitability, this research also added leverage, liquidity, and size as control variables to limit the effect of variables not included in the research that can impact with research results between the independent variables and the dependent variable.

\section{METHODS}

There is one dependent variable used in this research is Return on Assets (ROA) with four independent variables (CCC, ICP, ACP, and APP) and three controlling variables (leverage, size, and liquidity).

\section{Profitability (ROA)}

Return on Assets (ROA) ratio, is the profitability ratio to measure the company's 
performance calculated from net income after tax divided by the total assets mentioned by Yakubu, Alhassan, and Fuseini (2017). Research that uses ROA is Yakubu, Alhassan, and Fuseini (2017), Jakpar., Et., Al., (2017), and Mansoori and Muhammad (2012) as follows:

$$
\text { ROA }=\frac{\text { Net Income After Tax }}{\text { Total Assets }} \times 100 \%
$$

CCC

The conversion cycle shows how long it takes a company to convert resources into cash flow CCC is calculated by adding up the receivable period to the inventory period and minus the debt period this was explained by Yakubu, Alhassan, and Fuseini (2017). Research that uses the formula is Yakubu, Alhassan, and Fuseini (2017), Jakpar., Et., Al., (2017), Mansoori and Muhammad (2012), Mogaka and Jagongo (2013), and Ponsian, Chrispina, and Tago (2014) as follows:

Cash Conversion Cycle $=$ Inventory Conversion Period - Average Payment Period + Average Collection Period

\section{ICP}

ICP is the average time needed to convert raw materials into products for sale, said Alipour (2011). Research that uses the formula is Alipour (2011), Mogaka and Jagongo (2013), Yakubu, Alhassan, and Fuseini (2017) and as follows:

Inventory Conversion Period $=\frac{365 \text { Days }}{\text { Sales } / \text { Inventory }}$

\section{ACP}

ACP is the average time needed to convert a company's receivables into cash according to Alipour (2011). Research that uses the formula is Alipour (2011) and Yakubu, Alhassan, and Fuseini (2017) as follows:

Average Collection Period $=\frac{\text { Sales } / 365 \text { days }}{\text { Accounts Receivable }}$

\section{APP}

APP is the time needed by a company to complete the payment of a supplier or creditor according to Yakubu, Alhassan, and Fuseini (2017). Research that uses the formula is Alipour (2011), Mogaka and Jagongo (2013), and Yakubu, Alhassan, and Fuseini (2017) as follows:

Average Payment Period $=\frac{\text { Accounts } \text { Payable }}{\text { Sales } / 365 \text { days }}$

\section{Leverage}

In this research the leverage ratio using Total Debt divided by Total assets as in the study of Sharma and Kumar (2011), Mogaka and Jagongo (2013), and Samiloglu and Akgun (2016) as follows:

$$
\text { Leverage }=\frac{\text { Total Debt }}{\text { Total Assets }}
$$

\section{Liquidity}

The liquidity ratio in this research uses current assets divided by current liabilities as in Mogaka and Jagongo (2013) and Sharma and Kumar (2011) as follows:

$$
\text { Liquidity }=\frac{\text { Current Assets }}{\text { Current Liabilities }}
$$

\section{Size}

According to Kasozi (2017), the formula to measure the company size is as follows:

$$
\text { Size }=\ln (\text { Total Assets) }
$$

\section{Population and samples}

The population used in this research are manufacturing companies listed on the Indonesia Stock Exchange from 2013 to 2017. There are 129 companies divided into three sectors, namely chemical base manufacturing companies, various industrial manufacturing companies, and consumer goods manufacturing companies. The choice of manufacturing companies' sector because researchers want to focus on analyzing the relationship of working capital management to profitability for manufacturing companies engaged in production. Samples were taken using a 
Table 1.

Model 1 coefficient of determination

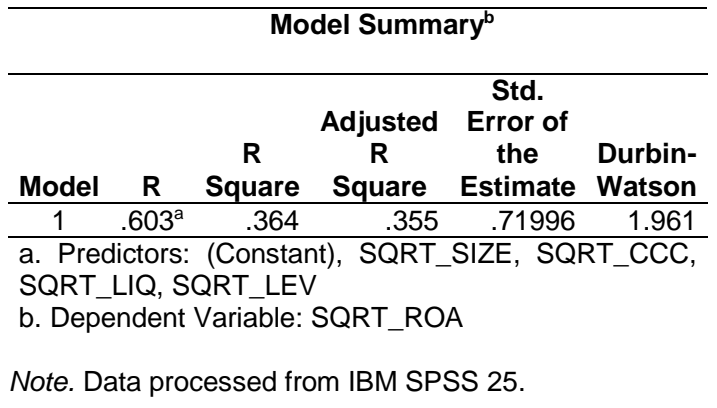

purposive sampling method with a total sample of 72 manufacturing companies based on sampling criteria such as companies listed on the Indonesia Stock Exchange in 2013-2017 wherein the period manufacturing companies have passed the crisis phase in 2008. in 2018 and 2019 financial statement data not yet available at the time of this research. For manufacturing companies that experience a 5-year profit and a positive cash cycle of 5 years used as purposive sampling because the data has passed the classic assumption test on SPSS.

\section{Analysis method}

The research methods used are consistent with previous studies such as Mansoori and Muhammad (2011), Mogaka and Jagongo (2013), and Bagh, Nazir, Khan, Khan, Razzaq (2018). The company's profitability model uses four core calculations of working capital management by adding other characteristics to the company. The research method used in this study using the Ordinary Least Square method can be formulated as follows:

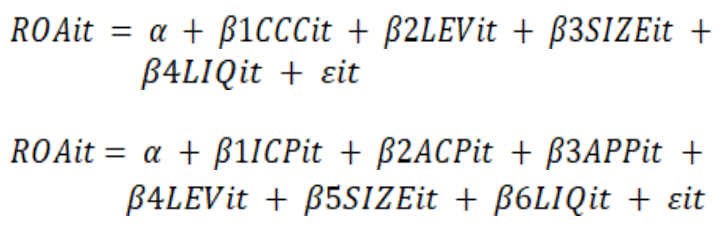

\section{Empirical analysis}

This research presented quantitative data using SPSS to test classical assumptions such as normality test, multicollinearity test, heteroscedasticity test, and autocorrelation test on models 1 and 2 .

\section{RESULTS AND DISCUSSION}

\section{Classic assumption testing}

Model 1 and 2 for the regression model has passed the classical assumption test such as normality test, multicollinearity test, heteroscedasticity test, and autocorrelation test. Based on the classic assumption test, model 1 and 2 has passed the classic assumption test.

\section{Coefficient of determination testing}

Testing the Coefficient of Determination according to Ghozali (2018) used in this research to measure how far the model's ability to explain variations in the dependent variable. This determination coefficient test can be seen from the adjusted $R^{2}$ ( $R$ square) value because the adjusted $R^{2}$ ( $R$ square) value can go up or down if one independent variable is added to the model according to Ghozali (2018).

In this research of model 1, the adjusted $R^{2}$ ( $R$ square) value is 0,355 . It means that $35.5 \%$ of dependent variables variety can be explained by the independent variables, and $64,5 \%$ of them are explained by the other factors.

Table 2.

Model 2 coefficient of determination

\begin{tabular}{|c|c|c|c|c|c|}
\hline \multicolumn{6}{|c|}{ Model Summary } \\
\hline Model & $\mathrm{R}$ & $\begin{array}{c}R \\
\text { Square }\end{array}$ & $\begin{array}{c}\text { Adjusted } \\
\text { R } \\
\text { Square }\end{array}$ & $\begin{array}{c}\text { Std. } \\
\text { Error of } \\
\text { the } \\
\text { Estimate }\end{array}$ & $\begin{array}{l}\text { Durbin- } \\
\text { Watson }\end{array}$ \\
\hline 1 & $.622^{\mathrm{a}}$ & .387 & .373 & .70970 & 2.068 \\
\hline $\begin{array}{l}\text { a. Pre } \\
\text { SQRT } \\
\text { b. Dep }\end{array}$ & $\begin{array}{l}\text { Q, S } \\
\text { dent }\end{array}$ & $\begin{array}{l}\text { Constar } \\
\text { QRT_AP } \\
\text { Variable }\end{array}$ & $\begin{array}{l}\text { SQRT } \\
\text { SQRT } \\
\text { QRT RR }\end{array}$ & $\begin{array}{l}\text { SIZE, SQ } \\
\text { ACP, SQR } \\
\text { OA }\end{array}$ & $\begin{array}{l}\text { RT_ICP, } \\
\text { IT_LEV }\end{array}$ \\
\hline
\end{tabular}

Note. Data processed from IBM SPSS 25. 
Table 3.

Model $1 \mathrm{~F}$ testing

\begin{tabular}{|c|c|c|c|c|c|c|}
\hline \multicolumn{7}{|c|}{ ANOVA $^{a}$} \\
\hline \multicolumn{2}{|r|}{ Model } & $\begin{array}{l}\text { Sum of } \\
\text { Squares }\end{array}$ & df & $\begin{array}{l}\text { Mean } \\
\text { Square }\end{array}$ & $\mathrm{F}$ & Sig. \\
\hline 1 & Regression & 82.228 & 4 & 20.557 & 39.659 & $.000^{\mathrm{b}}$ \\
\hline & Residual & 143.581 & 277 & .518 & & \\
\hline & Total & 225.810 & 281 & & & \\
\hline
\end{tabular}

a. Dependent Variable: SQRT_ROA

b. Predictors: (Constant), SQRT_SIZE, SQRT_CCC, SQRT_LIQ, SQRT_LEV

Note. Data processed from IBM SPSS 25.

In this research, the adjusted $R^{2}(R$ square) value is 0,373 . It means that $37.3 \%$ of dependent variables variety can be explained by the independent variables, and $62,7 \%$ of them are explained by the other factors.

\section{F Testing}

Ghozali (2018) states that testing using the $\mathrm{F}$ test is a test to find out all the independent variables entered into the model have a simultaneous effect on the dependent variable or not. Following is the $\mathrm{F}$ statistical test table for all models.

Table 3 shows a significant result $<0.05$, $F$ value 39.659 and significance value 0.000 . It shows that the independent variables have a simultaneous and significant effect on the dependent variable. It also shows that all variables have a significant effect.

Table 4 shows a significant result $<0.05$, $F$ value 28.887 and significance value 0.000 .
Table 4.

Model 2 F testing

\begin{tabular}{lrrrrrr}
\hline \multicolumn{7}{c}{ ANOVA $^{\mathrm{a}}$} \\
\hline \multicolumn{10}{c}{$\begin{array}{c}\text { Sum of } \\
\text { Model }\end{array}$} & $\begin{array}{c}\text { Mean } \\
\text { Squares }\end{array}$ & df & Square & $\mathrm{F}$ & Sig. \\
\hline 1 & Regression & 87.299 & 6 & 14.550 & 38.887 & $.000^{\mathrm{b}}$ \\
Residual & 138.511 & 275 & .504 & & \\
Total & 225.810 & 281 & & & \\
\end{tabular}

a. Dependent Variable: SQRT_ROA

b. Predictors: (Constant), SQRT_SIZE, SQRT_LIQ,

SQRT_APP, SQRT_ACP, SORT_LEV

Note. Data processed from IBM SPSS 25.

It shows that the independent variables have a simultaneous and significant effect on the dependent variable. It also shows that all variables have a significant effect.

\section{T Testing}

The T-test is a test used to show how far the effect of one independent variable individually in explaining the variation of independent variables according to Ghozali (2018). T-Test Results are shown in Table 5.

CCC produces t value -1.909 ; regression coefficient -0.029 ; and significance value 0.057 on real level $5 \%$. The equation in model 1 is as follows:

Model 1: $\mathrm{ROA}=-5.901-0.029 \mathrm{CCC}_{\mathrm{it}}-$ 1.841 LEV + 0.578 SIZE + 1.582 LIQ

The meaning of the equation is that shorten 1 day CCC will increase by $0.029 \%$ ROA.

Table 5.

Model $1 \mathrm{~T}$ testing

\begin{tabular}{|c|c|c|c|c|c|c|c|c|}
\hline \multicolumn{9}{|c|}{ Coefficients $^{\mathrm{a}}$} \\
\hline & \multirow[b]{2}{*}{ Model } & \multicolumn{2}{|c|}{$\begin{array}{c}\text { Unstandardized } \\
\text { Coefficients } \\
\text { Std. }\end{array}$} & \multirow{2}{*}{$\begin{array}{c}\text { Standardized } \\
\text { Coefficients } \\
\text { Beta }\end{array}$} & \multirow[b]{2}{*}{$t$} & \multirow[b]{2}{*}{ Sig. } & \multicolumn{2}{|c|}{ Collinearity Statistics } \\
\hline & & B & Error & & & & Tolerance & VIF \\
\hline 1 & (Constant) & -5.901 & 1.625 & & -3.632 & .000 & & \\
\hline & SQRT CCC & -.029 & .015 & -.096 & -1.909 & .057 & .900 & 1.111 \\
\hline & SQRT LEV & -1.841 & .302 & -.368 & -6.099 & .000 & .631 & 1.585 \\
\hline & SQRT_LIQ & .578 & .120 & .281 & 4.804 & .000 & .668 & 1.496 \\
\hline & SQRT SIZE & 1.582 & .300 & .261 & 5.279 & .000 & .943 & 1.061 \\
\hline
\end{tabular}

a. Dependent Variable: SQRT ROA

Note. Data processed from IBM SPSS 25. 
The results of statistical tests on the ICP model 2 produce a t-value of -0.777 and a regression coefficient of -0.013 with a significance value of 0.437 at $5 \%$ significance level, the ACP variable produces a t-value of -3.355 and a regression coefficient of -0.085 with a significance value of 0.001 at the $5 \%$ significance level, the APP variable produces a calculated value of 2.061 and a regression coefficient of 0.053 with a significance value of 0.040 at the $5 \%$ significance level.

The mathematical equation in model 4 research as follows:

Model 2: $\mathrm{ROA}=-4.524-0.013 \mathrm{ICP}-$ $0.085 \mathrm{ACP}+0.053 \mathrm{APP}+1.748 \mathrm{LEV}+$ 0.568 SIZE + 1.342 LIQ

\section{RESULTS AND DISCUSSION}

\section{The effect of CCC on profitability (ROA)}

Based on the results of statistical tests the effect of the CCC is negative and not significant. These results indicate that the shorter the CCC time, the faster the company will get profitability. However, this is not significant because manufacturing companies in Indonesia have shortened the time of their cash cycle but have little effect on increasing profitability. This result is also found in research conducted by Samiloglu and Akgun (2016) and Jakpar et al., (2017) which explain that the CCC has an insignificant negative effect on Return on Assets (ROA). Also, Jakpar et al., (2017) said that CCC has no significant negative effect on ROA because the CCC does not have much effect on the company's profitability even though the company has shortened inventory time, shortened the collection time of receivables, and delayed payment debt.

The test results also prove that manufacturing companies in Indonesia are by Myers and Majluf's (1984). pecking order theory which states that companies are more likely to choose to use internal funding. Insignificant results occurred due to the average period of the CCC.

\section{The effect of ICP on profitability (ROA)}

Based on the results of statistical tests the Effect of the ICP is negative and not significant. These results indicate that the shorter the ICP time, the faster the company will get profitability. This indicates that managers in making efficient operating decisions of the company have not been maximized and storage time still long so that profits on product sales are few. This indicates that the level of efficiency that is still lacking and the length of storage affects the level of profit increase that is not yet optimal

The results of this test same with research conducted by Samiloglu and Akgun (2016) and Yakubu, Alhassan, and Fuseini (2017). the ICP has an explained by Yakubu, Alhassan, and Fuseini (2017) that the longer the company in storing. The less working capital the company gets to finance company activities so that it can affect the company's performance.

Table 6.

Model $2 \mathrm{~T}$ testing

\begin{tabular}{|c|c|c|c|c|c|c|c|c|}
\hline \multicolumn{9}{|c|}{ Coefficients $^{a}$} \\
\hline & \multirow[b]{2}{*}{ Model } & \multicolumn{2}{|c|}{$\begin{array}{l}\text { Unstandardized } \\
\text { Coefficients }\end{array}$} & \multirow{2}{*}{$\begin{array}{l}\text { Standardized } \\
\text { Coefficients } \\
\text { Beta }\end{array}$} & \multirow[b]{2}{*}{$\mathbf{t}$} & \multirow[b]{2}{*}{ Sig. } & \multicolumn{2}{|c|}{ Collinearity Statistics } \\
\hline & & B & Std. Error & & & & Tolerance & VIF \\
\hline 1 & (Constant) & -4.524 & 1.717 & & -2.634 & .009 & & \\
\hline & SQRT_ICP & -.013 & .017 & -.038 & -.779 & .437 & .931 & 1.074 \\
\hline & SQRT_ACP & -.085 & .025 & -.172 & -3.355 & .001 & .853 & 1.173 \\
\hline & SQRT_APP & .053 & .026 & .108 & 2.061 & .040 & .812 & 1.231 \\
\hline & SQRT_LEV & -1.748 & .302 & -.349 & -5.796 & .000 & .614 & 1.629 \\
\hline & SQRT_LIQ & .568 & .124 & .277 & 4.571 & .000 & .609 & 1.642 \\
\hline & SQRT_SIZE & 1.342 & .306 & .221 & 4.390 & .000 & .880 & 1.136 \\
\hline
\end{tabular}

a. Dependent Variable: SQRT_ROA

Note. Data processed from IBM SPSS 25. 


\section{The effect of ACP on profitability (ROA)}

Based on the results of statistical tests the effect of the ACP is a negative and significant effect. These results indicate that the shorter the ACP, the faster the company eill get profitability. If the time needed to collect trade receivables is getting shorter, there will be lots of cash available so that cash can be used for further working capital. Conversely, the time needed to collect trade receivables is longer, si there will be less cash available so that the avallilable cash cannot be used for further working capital.

The results of this test are also by research by Jakpar, et. al. (2017), Yakubu, Alhassan, and Fuseini (2017), and Mogaka and Jagongo (2013) which explain that the ACP had significant negative effect on Return on Assets (ROA). Also, according to the finfings of the study, Yakubu, Alhassan, and Fuseini (2017) explained that companies in Ghana will perform well increase the profitability of the company.

\section{The effect of APP on profitability (ROA)}

Based on the results of statistical tests the effect of the APP is a positive and significant effect. This is because a long-range of debt payments can increase profitability. the company will need a long time in issuing cash and use the cash for the company's daily operations. Extending debt service will also increase the availability of cash that will be used for the needs of other companies' operations, this is done by many manufacturing companies in Indonesia.

The results of this test same with research conducted by Jakpar, et. al. (2017) and Mogaka and Jagongo (2013) which stated that the ACP had a significant positive effect on Return on Assets (ROA). Besides, according to the findings in this study described Mogaka and Jagongo (2013) stated that getting profitability at the company by delaying debt payments. The implication is that companies delay payments to suppliers to get the cash that will be used for working capital.

\section{The effect of control variables on profitability (ROA)}

Control variables function to isolate the impact of factors that have a relationship to the dependent variable but do not enter into the study so as not to affect the results of the study. The Leverage, Liquidity, and Size variables were selected as control variables in this study.

The test results show that leverage has a negative relationship with profitability (ROA). This shows that the smaller the company has external debt; it causes profitability to increase. However, if leverage decreases, there will be an increase in Return On Assets (ROA), vice versa.

The test results show that Liquidity has a positive relationship with profitability (ROA). This shows that the more cash owned by the company, it causes profitability to increase, but if Liquidity increases, it will be followed by an increase in Return on Assets (ROA), vice versa.

The test results show that Size has a positive relationship with profitability (ROA). This shows that the more assets owned by the company cause profitability to increase and vice versa. if Size increases, it will be followed by an increase in Return on Assets (ROA), vice versa.

\section{CONCLUSION}

The role of working capital management for profitability in Indonesia should not always be emphasized for company operations. It is illustrated that most manufacturing companies in Indonesia have large amounts of cash to maintain liquidity and to invest in working capital. This study establishes that the CCC has an insignificant negative relationship to profitability. This research recommends managing cash more wisely so that investment in working capital is maximized so that profitability increases. Besides that, the manager also succeeded in making the company's operations efficient even though in terms of storage time it still requires a long time.

This study found that the ICP has no significant negative relationship to profitability. This research recommends for manufacturing companies to be more efficient and shorten storage time to reduce production costs and get increased sales results so that profitability increases as well. then managers can maximize the availability of cash and increase profitability by reducing the time of accounts receivable this makes the ACP relationship has a significant negative relationship to profitability. This study recommends that the faster the 
receivables are collected, the more cash they have so that if invested in working capital, the profitability will be greater. Also, managers in manufacturing companies in Indonesia extend the time of debt repayment to the agreed maximum limit. This study also recommends that having a good relationship with suppliers can make debt payments take longer without having to experience limited raw materials and maintain the smooth operation of the company with better profitability.

\section{Research limitations}

We realize that there is still much deficiency in conducting this research such as, Adjusted R-Square in model 1 research of 0.355 is still relatively low because it means that the variation of independent variables that describe the dependent variation of $35.5 \%$ and $64.5 \%$ are still explained by other factors, and Adjusted R-Square research in model 2 of 0.373 is still relatively low because it means that the variation of independent variables that can describe the dependent variation of $37.3 \%$ and $62.7 \%$ is still explained by other factors, it is according to Ghozali (2018) that the value of Adjusted $R$-Square can go up or down if an independent variable is added to the model and the low Adjusted R-Square value also means that the factors that affect profitability in Indonesian manufacturing companies are not just from working capital management. Also, many manufacturing companies in this study did not have complete data in the study period so they had to be selected in advance for company data that was complete by predetermined research criteria.

\section{Future research agenda}

Based on the interpretation of the results and conclusions obtained, there are suggestions related to the research that this study can be a further reference on the effect of working capital on profitability for manufacturing companies in Indonesia with other sectors because for manufacturing companies in other sectors to find out the company's performance through capital management work and add other variables that have not been used in this study, such as sales growth by Mogaka and Jagongo (2013) and age by Bagh, Nazir, Khan, Khan, and Razzaq (2016) because in this study data for sales growth and age not many are available in the company's annual financial statements so this variable is not included in the study.

\section{REFERENCES}

Alipour, M. (2011). Working Capital Management and Corporate Profitability: Evidence from Iran. 12(7), 1093-1099

Bagh, T., Nazir, M. I., Khan, M. A., Khan, M. A., \& Razzaq, S. (2016). The impact of Working Capital Management on Firm's Financial Performance: Evidence from Pakistan. International Journal of Economics and Financial Issues, 6(3), 1097-1105.

Ghozali, I. (2018). Aplikasi Analisis Multivariate Dengan Program IBM SPSS 25 (9th ed.). Semarang: Badan Penerbit Undip.

Jakpar, S., Tinggi, M., Johari, A., Siang, T., Myint, K., \& Sadique, M. (2017). Working Capital Management and Profitability: Evidence from Manufacturing Sector in Malaysia. Journal of Business \& Financial Affairs, 06(02). https://doi.org/10.4172/21670234.1000255

Kasozi, J. (2017). The effect of working capital management on profitability: a case of listed manufacturing firms in South Africa. Investment management and financial innovations, 14(2), 336-346.

Makori, D. M., \& Jagongo, A. (2013). Working Capital Management and Firm Profitability: Empirical Evidence from Manufacturing and Construction Firms Listed on Nairobi Securities Exchange, Kenya. International Journal of Accounting and Taxation, 1(1). https://doi.org/10.15640/ijat

Mansoori, E., \& Muhammad, J. (2012). The Effect of Working Capital Management on Firm's Profitability: Evidence from Singapore. 472-486.

Mogaka, D., \& Jagongo, A. (2013). Working Capital Management and Firm Profitability. International Journal of Accounting and Taxation.

Myers, S. C., \& Majluf, N. S. (1984). Brealey, Richard A., Stewart C. Myers, and Franklin Allen. Principles of Corporate Finance. New York: McGraw-Hill/Irwin, 2011. Print., 13(2), 187-221. https://doi.org/10.1016/0304405X(84)90023-0

Ponsian, N., Chrispina, K., Tago, G., \& Mkiibi, H. (2014). The Effect of Working Capital 
Management on Profitability. International Journal of Economics,

Finance and Management Sciences, 2(6),

347.

https://doi.org/10.11648/j.ijefm.2014020

6.17

Richards, V. D., \& Laughlin, E. J. (2012). to Cycle Approach Liquidity Analysis. 9(1), 3238.

Şamiloğlu, F., \& Akgün, A. İ. A. (2016). The Relationship between Working Capital Management and Profitability. The Relationship between Working Capital Management and Profitability: Evidence from Turkey, 7(2), 1-14. https://doi.org/10.20409/berj.20162174 92

Shah, B., Gujar, M. A., \& Sohu, N., U. (2018). The Impact of Working Capital Management and Profitability: Case Study of Pharmaceutical and Chemical Firms Listed on Karachi Stock Exchange Email address: International Journal of Economics, Commerce and Management, 6(3), 200-220.

Sharma, A. K., \& Kumar, S. (2011). Effect of working capital management on firm profitability: Empirical evidence from India. Global Business Review. https://doi.org/10.1177/0972150910012 00110

Vural, G., Sokmen, A. G., \& Cetenak, E. H. (2012). Affects of Working Capital Management on Firm's Performance: Evidence from Turkey. 2(4), 488-495.

Yakubu, I. N., Alhassan, M. M., \& Fuseini, A. A. (2017). The impact of working capital management on corporate performance: Evidence from listed non-financial firms in Ghana. 